\title{
Depressurization and boiling of a single magmatic fluid as a mechanism for tin-tungsten deposit formation
}

\author{
Journal Article \\ Author(s): \\ Korges, Maximilian; Weis, Philipp; Lüders, Volker; Laurent, Oscar \\ Publication date: \\ 2017-11 \\ Permanent link: \\ https://doi.org/10.3929/ethz-b-000278300 \\ Rights / license: \\ In Copyright - Non-Commercial Use Permitted \\ Originally published in: \\ Geology 46(1), https://doi.org/10.1130/G39601.1
}


This is the Green Open Access version of: Korges, M., Weis, P., Lüders, V., Laurent, O., 2018. Depressurization and boiling of a single magmatic fluid as a mechanism for tin-tungsten deposit formation. Geology, v. 46, no. 1, p. 75-78.

Original publication see: https://doi.org/10.1130/G39601.1

\title{
Depressurization and boiling of a single magmatic fluid as a mechanism for tin-tungsten deposit formation
}

\author{
Maximilian Korges ${ }^{1}$, Philipp Weis ${ }^{1}$, Volker Lüders ${ }^{1}$, and Oscar Laurent ${ }^{2}$ \\ ${ }^{1}$ GFZ German Research Centre for Geosciences, Telegrafenberg, 14473 Potsdam, \\ Germany \\ ${ }^{2}$ ETH Zurich, Institute of Geochemistry and Petrology, 8092 Zurich, Switzerland
}

\begin{abstract}
Tin (Sn) and tungsten (W) mineralization are often associated with each other in relation to highly evolved granites, but economical ore grades are restricted to rare global occurrences and mineralization styles are highly variable, indicating different mechanisms for ore formation. The Sn-W Zinnwald deposit in the Erzgebirge (Germany/Czech Republic) in the roof zone of a Variscan Li-F granite hosts two contrasting styles of mineralization: 1) cassiterite ( $\mathrm{Sn}$ ) in greisen bodies and 2) cassiterite and wolframite (W) in predominantly sub-horizontal quartz-rich veins. The relative timing and causes for ore formation remain elusive. Studies of fluid inclusion assemblages in wolframite, cassiterite and quartz samples from greisen and veins by conventional and infrared microthermometry and LA-ICP-MS analyses have revealed compelling evidence that all elements required for the formation of the Zinnwald Sn-W deposit were contained in a single parental magmatic-hydrothermal fluid that underwent two main processes: 1) fluid-rock interaction during Sn-greisen formation and 2) depressurization and vapor loss leading to ore precipitation in quartz-Sn-W veins. The results also show that fluid inclusion assemblages in ore minerals can document fluid processes that are absent in the fluid inclusion record of gangue minerals. The study further highlights the role of phase separation in the formation of W-rich Sn-deposits and indicates that W-deposits in distal parts of evolved granites may be restricted to fluids derived from deeper-seated plutons.
\end{abstract}

\section{INTRODUCTION}

Natural enrichments of tin (Sn) and tungsten (W) to economic grades are typically associated with evolved A- or S-type granites in major orogenic settings (e.g., Romer and Kroner (2016) and references therein). Sn, W or Sn-W mineralization are hosted in metasomatized roof zones (greisen) and/or hydrothermal veins, which can be 
located proximal within the intrusion, e.g., Erzgebirge, Germany/Czech Republic (Stemprok, 1967) and East Kemptville, Canada (Halter et al., 1998), or may extend to more distal parts into the surrounding rocks, e.g., Panasqueira, Portugal (Kelly and Rye, 1979) and Pasto Bueno, Peru (Landis and Rye, 1974). However, fluid sources and pathways as well as their temporal and spatial evolution which lead to Sn-W ore precipitation often remain debated.

Within the same deposit, precipitation of cassiterite, wolframite and other ore minerals have occurred contemporaneously or successively, indicating that several geologic controls can trigger ore deposition. Greisen formation has mainly been attributed to hydrolysis of feldspars (Stemprok, 1987; Stemprok and Sulcek, 1969) by magmatic fluids, with $\mathrm{pH}$ decrease leading to Sn precipitation (Schmidt, 2016). Snvein formation at Mole Granite, Australia (Audétat et al., 2000) and W-Sn-vein formation at Vaulry, France (Vallance et al., 2001) are related to mixing of magmatic and meteoric fluids. W-mineralization at Panasqueira has been attributed to fluidrock reactions of $\mathrm{W}$-rich, Fe-poor magmatic fluids with Fe-rich metasedimentary host rocks (Lecumberri-Sanchez et al., 2017). Phase separation has further been identified as a potential mechanism for ore deposition, albeit with a subordinate efficiency to form an economic ore deposit (Heinrich, 1990). About half of the global W production comes from vein, stockwork, breccia, and porphyry deposits and only 5\% from disseminated greisen mineralization, which in contrast is the main source for $\mathrm{Sn}$ (Pitfield et al., 2011).

Infrared microthermometry and LA-ICP-MS analyses of fluid inclusion assemblages (FIA) in ore minerals such as cassiterite and wolframite can provide direct insights to temperature, salinity and chemistry of ore-forming fluids (Lüders, 2017), but LA-ICPMS analyses of ore-hosted fluid inclusions (FIs) require a very precise documentation of the location of fluid inclusions prior to ablation (Kouzmanov et al., 2010).

\section{THE ZINNWALD SN-W DEPOSIT}

The Zinnwald/Cínovec deposit is located on both sides of the German/Czech border in the eastern part of the Erzgebirge, which is part of the Saxothuringian Zone of the Variscan Orogeny (Fig. 1). The deposit is related to the evolved Li-F Zinnwald granite (Förster et al., 1998) and hosts two mineralization styles: 1) Sn in greisen (Fig. 1B) and 2) proximal Sn-W-veins (Fig. 1D) within the metasomatized roof zone of the granitic intrusion (Appendix for detailed geology). Fluid inclusion microthermometry in quartz and cassiterite from tin-tungsten deposits in the Erzgebirge showed a predominance of intermediate-density fluids and temperatures between 360 and 400 ${ }^{\circ} \mathrm{C}$ for ore formation (Thomas, 1982). Studies of wolframite-hosted fluid inclusions from the Zinnwald deposit yielded homogenization temperatures between 300 and $360^{\circ} \mathrm{C}$ and variable salinity (Lüders, 1996). Few LA-ICP-MS measurements of fluid inclusions in quartz from the Zinnwald Sn-W deposit have been performed in rare boiling assemblages at higher temperatures of ca. $470{ }^{\circ} \mathrm{C}$ (Heinrich et al., 1999). However, the fluid evolution in Zinnwald and ore formation remains debated.

For this study, we collected samples from quartz veins from the German part of the mine at the northern flank of the granite (Fig. 1A). Additional historic samples 
containing euhedral crystals of cassiterite, wolframite and quartz were provided from mineral collections. Fluid inclusion in 25 selected samples of quartz and ore minerals were studied by microthermometry (convectional and infrared), isotope ratio mass spectrometry and LA-ICP-MS (see Appendix for detailed method description).
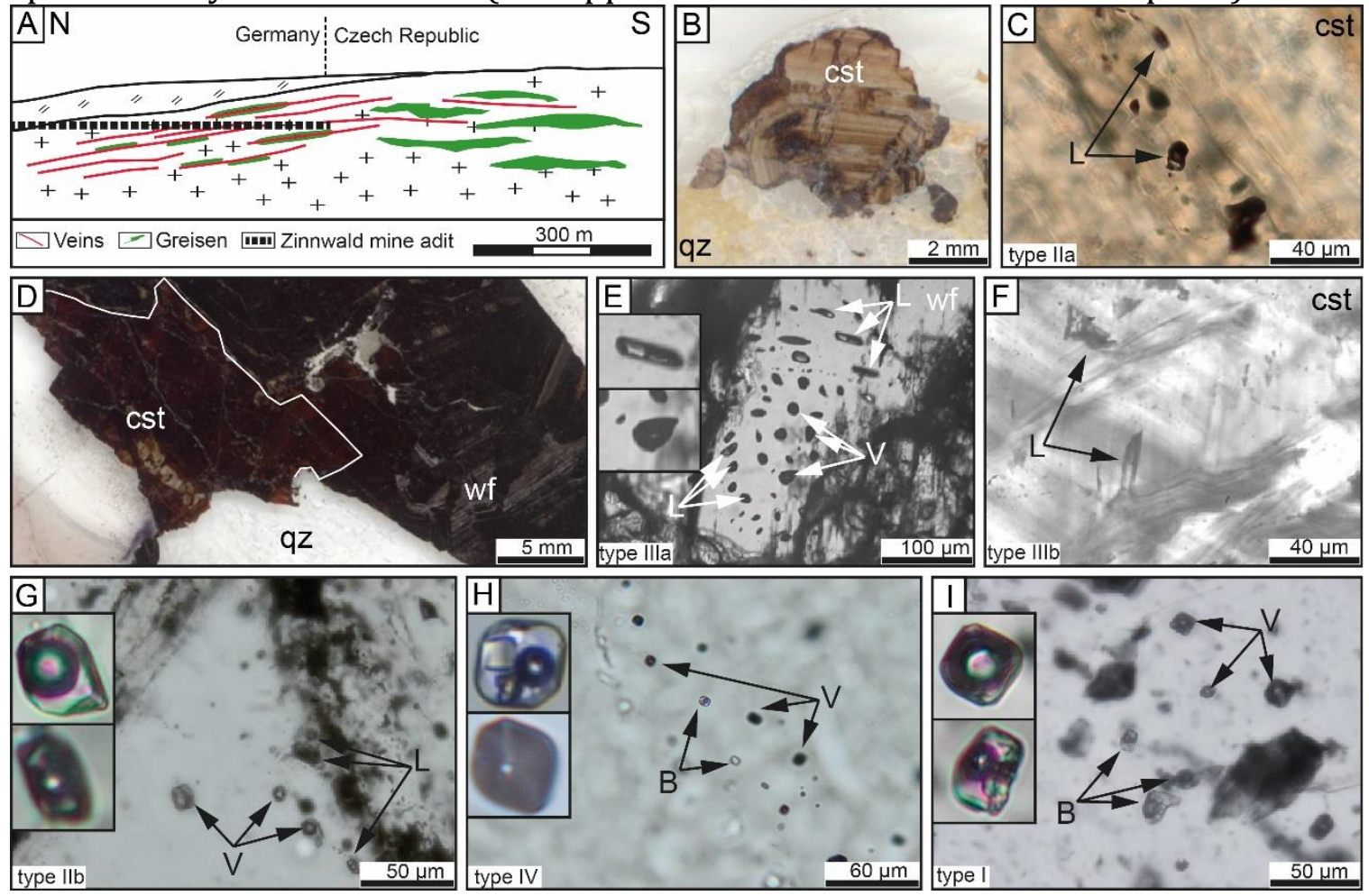

Figure 1. A: Schematic cross section through the roof zone of the Zinnwald granite showing the sampling area (adit) with greisen and vein-type mineralization. B + C: Greisen sample with quartz (qz) and cassiterite (cst) showing growth zones with primary liquid-rich (L) inclusions. D: Wolframite (wf) intimately intergrown with cassiterite indicating contemporaneous deposition in the vein. E: Wolframite with a boiling assemblage of liquidrich and vapor-rich (V) inclusions. F: Cassiterite with intermediate density inclusions orientated along growth zones. G: Fluid inclusion assemblage in the wake of a quartz growth zone showing different homogenization behavior: $\mathrm{L}$ to liquid, $\mathrm{V}$ to vapor. $\mathrm{H}$ : Trail of a boiling assemblage with pseudosecondary brine-type inclusions (B) in quartz. I: High-temperature boiling assemblage in a quartz growth zone with hypersaline brines.

\section{RESULTS}

The studied quartz samples are often recrystallized and host abundant secondary fluid inclusions. Rare primary and pseudosecondary fluid inclusions and fluid inclusion assemblages hosted in quartz, cassiterite and wolframite were classified after Roedder (1984) and define four different inclusion types (Fig. 2A). Type I hightemperature brine inclusions from boiling assemblages hosted in a re-analyzed quartz sample from Heinrich et al. (1999) and in one quartz sample from the BGR collection yield salinities of ca. 40 wt.\% $\mathrm{NaCl}$ equiv. and homogenization temperatures between 420 and $490{ }^{\circ} \mathrm{C}$ (Fig. 1I). The most common primary fluid inclusions (type II) decorate growth zones and are aqueous two-phase inclusions with liquid to vapor ratios of $\sim 1: 1$. They are hosted in greisen (quartz and cassiterite: type IIa; Fig. 1C) as well as in vein quartz (type IIb; Fig. 1G). Type II inclusions commonly homogenize into the liquid phase between $350^{\circ} \mathrm{C}$ and $410{ }^{\circ} \mathrm{C}$, but in rare 
FIAs they homogenize either into the liquid or vapor phase (Fig. 1G) or even show critical homogenization. Salinities of type II inclusions range between 1 and $8.5 \mathrm{wt} . \%$ $\mathrm{NaCl}$ equiv. Type III inclusions are aqueous two-phase inclusions hosted in wolframite (type IIIa; Fig. 1E) and cassiterite (type IIIb; Fig. 1F) in veins. Most type IIIa inclusions are liquid-rich, have homogenization temperatures between 340 and $350^{\circ} \mathrm{C}$ and salinities of $10-12 \mathrm{wt} . \% \mathrm{NaCl}$ equiv. Type IIIa inclusions are locally found in boiling assemblages (Fig. 1E). Type IIIb inclusions in cassiterite have lower homogenization temperatures of ca. $335^{\circ} \mathrm{C}$ and higher salinities of $\sim 14 \mathrm{wt} . \% \mathrm{NaCl}$ equiv. even though cassiterite is intimately intergrown with wolframite. Type III inclusions are not contained in quartz, not even in quartz intergrown with wolframite (Fig. 1D). Rare type IV fluid inclusion low-temperature boiling assemblages were observed in two samples from a quartz vein (Fig. 1H). The samples host abundant small vapor-rich inclusions besides brine inclusions which mostly contain two to three solid phases and have salinities around $30 \mathrm{wt} \% \mathrm{NaCl}$ equiv. and homogenization temperatures of ca. $300^{\circ} \mathrm{C}$.
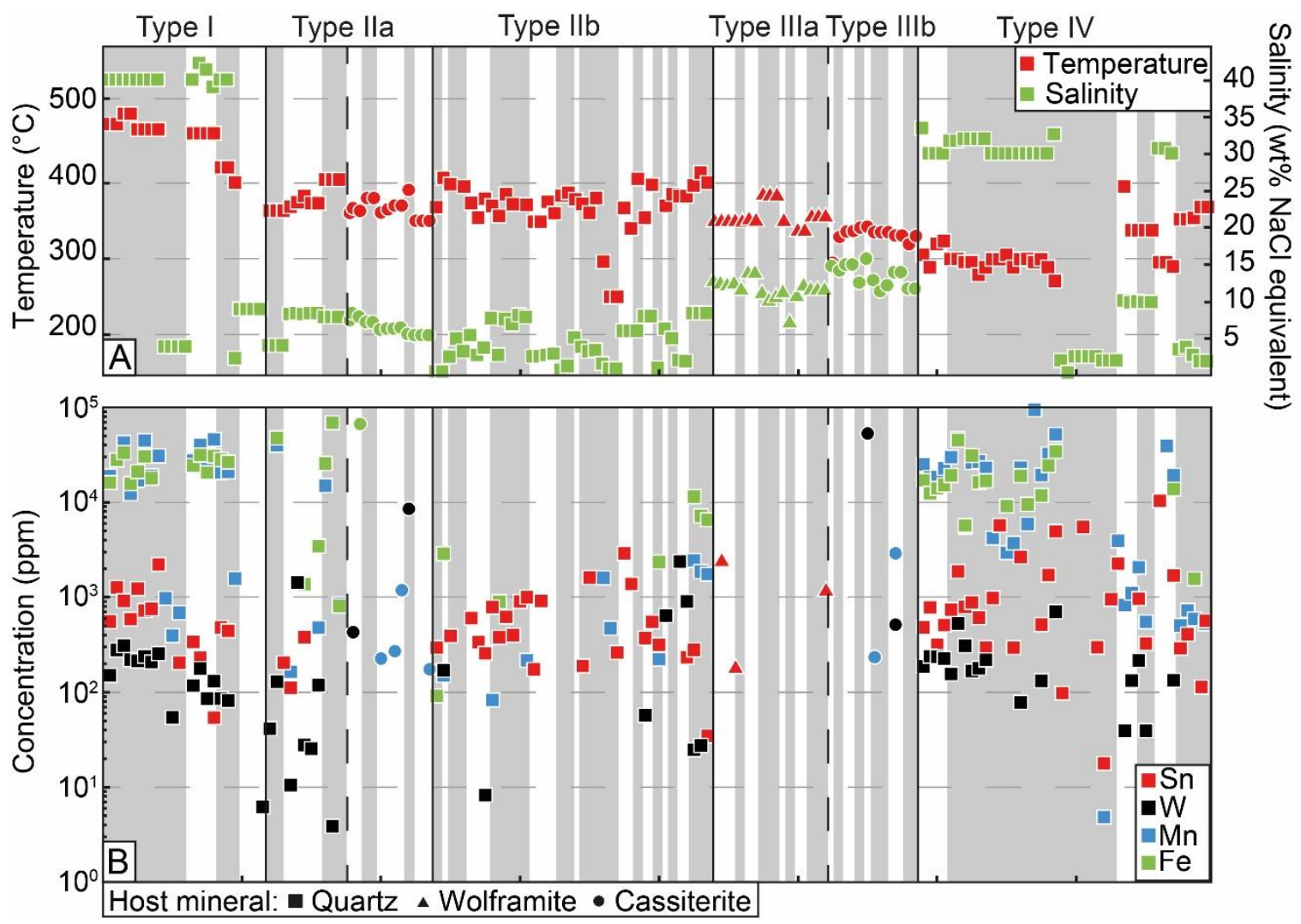

Figure 2. A: Homogenization temperatures and salinities of different fluid inclusion types (I - IV) in quartz (squares), cassiterite (circles) and wolframite (triangles). Grey and white fields group individual fluid inclusion assemblages. B: Element contents in fluid inclusions by LA-ICP-MS.

LA-ICP-MS analyses show that all elements necessary for the formation of cassiterite (Sn) and wolframite (Mn, Fe, W) can be detected in all inclusion types (Fig. 2B). Sn contents are slightly higher in the boiling assemblages (I, IV) than in type IIb 
inclusions. Wolframite has higher traces of Sn, but some type IIIa inclusions have detectable Sn contents of up to $2400 \mathrm{ppm}$. Relevant metals for the formation of wolframite are more enriched in brine-type inclusions and have similar contents in greisen (IIa) and vein quartz (IIb).

The different fluid inclusion types show a strong similarity in chemical compositions, suggesting a common source fluid, with variations mainly depending on different salinities due to phase separation and fractionation. A single fluid source is best documented by various almost linear positive correlations, e.g., $\mathrm{Cs} / \mathrm{Na}$ versus $\mathrm{Rb} / \mathrm{Na}$ ratios and As versus Cs contents (Fig. $3 \mathrm{~A}+\mathrm{B}$ ) and homogeneous $0^{13} \mathrm{C} \mathrm{Co}$ values of fluid inclusions in quartz and cassiterite between 05.5 and $07 \%$, which is consistent with a magmatic fluid source (e.g. Fuex and Baker, 1973). The geochemical data further show that fluid inclusions in all type II inclusions have similar element contents whereas the FI from boiling assemblages (type I, III, IV) form a distinct cluster of high element concentrations (see Appendix for statistical values).

\section{FLUID EVOLUTION}

Type IV FIA allow a direct estimate of the fluid pressures during vein formation because they are tied to the two-phase liquid-vapor (LV) coexistence curve, yielding fluid pressures of $\sim 60-100$ bar (Fig. 3C). Type IIb inclusions with variable salinities lack boiling assemblages and yield minimum entrapment pressures between 150 and 330 bar. Their variable homogenization behavior indicate that they were also likely trapped at or near the LV-coexistence and that the salinity variations of $1-10 \mathrm{wt} . \%$ $\mathrm{NaCl}$ equiv. reflect gentle boiling. Since all sampled veins represent a similar depth level (Fig. 1A) and type II and IV inclusions occur in the same vein, the pressure variation with a factor $1.5-5.5$ can best be explained by transition from a (nearly) lithostatic to a (nearly) hydrostatic pressure regime, suggesting a paleodepth of $\sim 1$ $2 \mathrm{~km}$ in agreement with estimates for the granite intrusion depth (Dolejš and Stemprok, 2001). Lithostatic fluid pressure conditions have been inferred as a possible mechanism for the formation of sub-horizontal veins by hydraulic fracturing during fluid exsolution from a crystallizing magma chamber (Breiter et al., 2017; Foxford et al., 2000).

Type I inclusions hosted in historic quartz samples yield higher pressure conditions between 250 and 450 bar during fluid entrapment, suggesting sample origin from deeper parts of the deposit. The high temperatures partially narrow the temperature gap between an assumed solidus temperature of the granite of $\sim 650^{\circ} \mathrm{C}$ (Johannes, 1984 ) and the average mineralization temperature of $380^{\circ} \mathrm{C}$. 

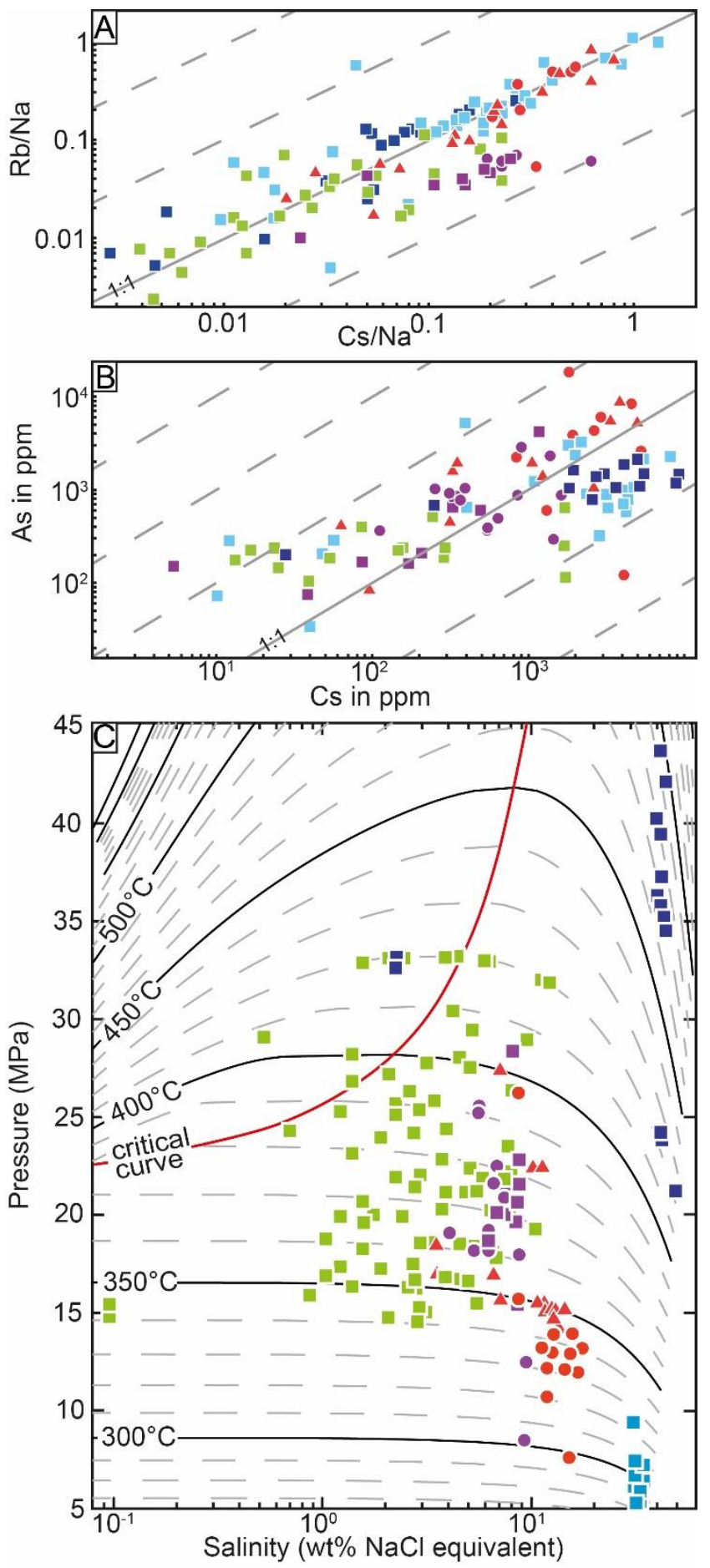

$$
\begin{array}{|ll|}
\hline \text { - Type I (qz, boiling) } & \text { - Type Ila (greisen, qz) } \\
\text { - Type Ila (greisen, cst) } & \text { - Type Ilb (vein, qz) } \\
\text { \Type Illa (vein, wf) } & \text { - Type IIlb (vein, cst) } \\
\text { - Type IV (vein, qz, boiling) } &
\end{array}
$$

Figure 3. A + B: $\mathrm{Cs} / \mathrm{Na}$ versus $\mathrm{Rb} / \mathrm{Na}$ ratios and $\mathrm{Cs}$ versus As contents of different fluid inclusion types showing near-linear trends. C: Pressure estimates from homogenization temperatures and salinities. Fluid inclusions of type IIa in Greisen overlap with type IIb inclusions. Fluid inclusions of type IIIa and IIIb in vein wolframite and cassiterite form a distinct field between type II and type IV brine inclusions. Fluid pressures, phase relations and isotherms are calculated after Driesner and Heinrich (2007). 


\section{ORE PRECIPITATION}

The type III inclusions in ore minerals from vein mineralization follow the same trend of decreasing pressures and temperatures and increasing salinities along the twophase coexistence field. Their entrapment conditions are positioned in the middle between the inclusions representing the lithostatic (type II) and the hydrostatic (type IV) endmembers of the fluid evolution in the veins. This interpretation is confirmed by the presence of boiling FIAs in wolframite (type IIIa) and their geochemical similarities to other boiling FIAs. The FIA in the intergrown wolframite-cassiterite sample form slightly different types (IIIa and IIIb, respectively), which suggests a rapid, dynamic process during ore deposition, such as depressurization during fracture opening. A transient pressure drop from nearly-litohstatic to sub-hydrostatic conditions leads to partial loss of the high-enthalpy vapor phase, resulting in cooling and salinity increase of the remaining brine.

The similarities in chemical composition and partial overlap of fluid inclusions types IIa (greisen) and IIb (vein quartz) suggest a simultaneous formation of vein and greisen in Zinnwald, which is in line with geological observations at the mine where quartz veins can be hosted by greisen, granite (not greisenized) or partially by granite and greisen.

Our interpretation suggests two contrasting processes of Sn-W deposition for greisen and vein mineralization: (1) fluid-rock reaction and (2) phase separation. Sn can be transported as $\mathrm{Sn}$ (II) or Sn(IV) by complexation with $\mathrm{Cl}^{-}$in the fluid whereas $\mathrm{W}$ is in solution as $\mathrm{WO}_{4}^{2-}$. Therefore, $\mathrm{SnO}_{2}$ (cassiterite) can be precipitated by removing $\mathrm{HCl}$ from the fluid system (Schmidt, 2016):

$$
\begin{aligned}
& {\left[\mathrm{SnCl}_{4}\left(\mathrm{H}_{2} \mathrm{O}\right)_{2}\right]^{0}=\mathrm{SnO}_{2}+4 \mathrm{HCl}} \\
& {\left[\mathrm{SnCl}_{3}\right]^{-}+\mathrm{H}^{+}+2 \mathrm{H}_{2} \mathrm{O}=\mathrm{SnO}_{2}+3 \mathrm{HCl}+\mathrm{H}_{2}}
\end{aligned}
$$

Wolframite precipitation needs additional cations (here, Fe and $\mathrm{Mn}$ ) which are also mostly transported as complexes with $\mathrm{Cl}^{-}$(Heinrich, 1990):

$$
\mathrm{H}_{2} \mathrm{WO}_{4}+(\mathrm{Fe}, \mathrm{Mn}) \mathrm{Cl}_{2}=(\mathrm{Fe}, \mathrm{Mn}) \mathrm{WO}_{4}+2 \mathrm{HCl}
$$

Greisenization (hydrolysis of feldspars and biotite) moves the Sn-reactions $(1,2)$ to the right and can therefore precipitate cassiterite, whereas $\mathrm{W}$ can still stay in solution, e.g., if $\mathrm{Fe}$ and $\mathrm{Mn}$ are consumed for the formation of zinnwaldite (Tischendorf et al., 1997). During fluid phase separation volatile elements (e.g., $\mathrm{HCl}, \mathrm{Cl}^{-}, \mathrm{H}^{+}$) preferentially partition into the vapor phase (Bischoff et al., 1996; Simonson and Palmer, 1993) which can readily leave the system due to its low density, leading to a change in the chemical composition of the fluid and therefore to cassiterite and simultaneous wolframite precipitation (Heinrich, 1990).

Phase separation during vein opening may be episodic, but the presence of a brine phase and the absence of pure vapor inclusions exclude extreme pressure drops during flashing events (Clark and Williams-Jones, 1990; Moncada et al., 2017). Ore 
precipitation due to phase separation with the proposed mechanism will be most efficient at relatively low pressures where the vapor phase has a very low density. This relation suggests that greisen deposits with Sn-W-rich veins are more favorably associated with shallow intrusions, while fluids exsolved from deeper intrusions may be capable of avoiding wolframite precipitation by phase separation and allow metal transport to more distal parts, where fluids can interact with the surrounding rocks (e.g. Polya, 1989).

\section{CONCLUSIONS}

Our fluid inclusion study suggests that contrasting mineralization styles at the Sn-W Zinnwald deposit, Erzgebirge formed from a single magmatic fluid:

1. Feldspar hydrolysis during fluid-rock interaction in the roof of an evolved granitic intrusion leads to the formation of cassiterite-bearing greisen bodies.

2. Transient changes of the pressure regime from lithostatic to (sub-)hydrostatic conditions due to vein opening leads to phase separation and vapor loss, triggering coeval precipitation of wolframite and cassiterite in quartz veins within the greisenized cupola.

The fluid inclusion data, together with geological observations at the mine, suggest that both precipitation mechanisms happen roughly at the same time. The results of this study also show that fluid inclusion assemblages in ore minerals can form distinct compositional fields, which may be overlooked or not even documented in primary growth zones in coexisting vein quartz, highlighting the importance of fluid inclusion analyses in ore minerals as direct evidence for ore formation in dynamic hydrothermal systems.

\section{ACKNOWLEDGMENTS}

We thank the HU Berlin and BGR Hannover for samples from their mineral collections and the guides from the Zinnwald visitors mine as well as GEOS Engineers Company for sampling allowance and support. We further thank M. Sośnicka, C. Schmidt and K. Schlöglova for fruitful discussions. Insightful comments and suggestions from M. Barton and two anonymous reviewers helped to improve the manuscript. The project was funded by the German Federal Ministry of Education and Research (BMBF) within the project GRAMME (033R149).

\section{REFERENCES CITED}

Audétat, A., Günther, D., and Heinrich, C.A., 2000, Causes for large-scale metal zonation around mineralized plutons: Fluid inclusion LA-ICP-MS evidence from the Mole Granite, Australia: Economic Geology and the Bulletin of the Society of Economic Geologists, v. 95, p. 1563-1581, https://doi.org/10.2113/gsecongeo.95.8.1563.

Bischoff, J.L., Rosenbauer, R.J., and Fournier, R.O., 1996, The generation of $\mathrm{HCl}$ in the system $\mathrm{CaCl} 2-\mathrm{H} 2 \mathrm{O}$ : Vapor-liquid relations from 380-500 C: Geochimica et 
Cosmochimica Acta, v. 60, p. 7-16, https://doi.org/10.1016/0016-7037(95)00365-

7.

Breiter, K., Ďurišová, J., Hrstka, T., Korbelová, Z., Vaňková, M., Galiová, M. V., Kanický, V., Rambousek, P., Knésl, I., and Dobeš, P., 2017, Assessment of magmatic vs. metasomatic processes in rare-metal granites: A case study of the Cínovec/Zinnwald Sn-W-Li deposit, Central Europe: Lithos, v. ${ }^{\circ} 292-293$, p. ${ }^{\circ} 198-217$, https://doi.org/10.1016/j.lithos.2017.08.015.

Clark, J. R., and Williams-Jones, A. E., 1990, Analogues of epithermal gold-silver deposition in geothermal well scales: Nature, v. ${ }^{\circ} 346$, p. $^{\circ} 644-645$, https://doi.org/10.1038/346644a0.

Dolejš, D., and Stemprok, M., 2001, Magmatic and hydrothermal evolution ofLiF granites: Cínovec and Krásnointrusions, Krušné hory batholith, Czech Republic: Bulletin of Czech Geological Survey, v. 76, p. 77-99.

Driesner, T., and Heinrich, C. A., 2007, The system H2O-NaCl. Part I: Correlation formulae for phase relations in temperature-pressure-composition space from 0 to $1000^{\circ} \mathrm{C}, 0$ to $5000 \mathrm{bar}$, and 0 to $1 \mathrm{XNaCl}$ : Geochimica et Cosmochimica Acta, v. ${ }^{\circ} 71$, p. ${ }^{\circ} 4880-4901$, https://doi.org/10.1016/j.gca.2006.01.033.

Förster, H.-J., Tischendorf, G., Seltmann, R., and Gottesmann, B., 1998, Die variszischen Granite des Erzgebirges: Neue Aspekte aus stofflicher Sicht: Zeitschrift für Geologische Wissenschaften, v. 26, p. 31-60.

Foxford, K., Nicholson, R., Polya, D., and Hebblethwaite, R., 2000, Extensional failure and hydraulic valving at Minas da Panasqueira, Portugal: evidence from vein spatial distributions, displacements and geometries: Journal of Structural Geology, v. 22, p. 1065-1086, https://doi.org/10.1016/S0191-8141(00)00029-8.

Fuex, A., and Baker, D.R., 1973, Stable carbon isotopes in selected granitic, mafic, and ultramafic igneous rocks: Geochimica et Cosmochimica Acta, v. 37, p. 2509-2521, https://doi.org/10.1016/0016-7037(73)90295-0.

Halter, W.E., Williams-Jones, A.E., and Kontak, D.J., 1998, Modeling fluid-rock interaction during greisenization at the East Kemptville tin deposit: Implications for mineralization: Chemical Geology, v. 150, p. 1-17, https://doi.org/10.1016/S00092541(98)00050-3.

Heinrich, C.A., 1990, The Chemistry of Hydrothermal Tin (-Tungsten) Ore Deposition: Economic Geology and the Bulletin of the Society of Economic Geologists, v. 85, p. 457-481, https://doi.org/10.2113/gsecongeo.85.3.457.

Heinrich, C.A., Günther, D., Audétat, A., Ulrich, T., and Frischknecht, R., 1999, Metal fractionation between magmatic brine and vapor, determined by microanalysis of fluid inclusions: Geology, v. 27, p. 755-758, https://doi.org/10.1130/0091-7613(1999)027<0755:MFBMBA>2.3.CO;2.

Johannes, W. (1984), Beginning of melting in the granite system Qz-Or-Ab-An$\mathrm{H}_{2} \mathrm{O}$ : Contributions to Mineralogy and Petrology, v. ${ }^{\circ} 86(3)$, p. ${ }^{\circ} 264-273$, https://doi.org/10.1007/BF00373672

Kelly, W.C., and Rye, R.O., 1979, Geologic, fluid inclusion, and stable isotope studies of the tin-tungsten deposits of Panasqueira, Portugal: Economic Geology and the Bulletin of the Society of Economic Geologists, v. 74, p. 1721-1822, https://doi.org/10.2113/gsecongeo.74.8.1721. 
Kouzmanov, K., Pettke, T., and Heinrich, C.A., 2010, Direct analysis of oreprecipitating fluids: Combined IR microscopy and LA-ICP-MS study of fluid inclusions in opaque ore minerals: Economic Geology and the Bulletin of the Society of Economic Geologists, v. 105, p. 351-373, https://doi.org/10.2113/gsecongeo.105.2.351.

Landis, G.P., and Rye, R.O., 1974, Geologic, Fluid Inclusion, and Stable Isotope Studies of the Pasto Buena Tungsten-Base Metal Ore Deposit, Northern Peru: Economic Geology and the Bulletin of the Society of Economic Geologists, v. 69, p. 1025-1059, https://doi.org/10.2113/gsecongeo.69.7.1025.

Lecumberri-Sanchez, P., Vieira, R., Heinrich, C., Pinto, F., and Wälle, M., 2017, Fluid-rock interaction is decisive for the formation of tungsten deposits: Geology, v. 45, p. 579-582, https://doi.org/10.1130/G38974.1.

Lüders, V., 1996, Contribution of infrared microscopy to fluid inclusion studies in some opaque minerals (wolframite, stibnite, bournonite); metallogenic implications: Economic Geology and the Bulletin of the Society of Economic Geologists, v. 91, p. 1462-1468, https://doi.org/10.2113/gsecongeo.91.8.1462.

-, 2017, Contribution of infrared microscopy to studies of fluid inclusions hosted in some opaque ore minerals: possibilities, limitations, and perspectives: Mineralium Deposita, v. 52, p. 663-673, https://doi.org/10.1007/s00126-0160694-4.

Moncada, D., Baker, D., and Bodnar, R.J., 2017, Mineralogical, petrographic and fluid inclusion evidence for the link between boiling and epithermal Ag-Au mineralization in the La Luz area, Guanajuato Mining District, México: Ore Geology Reviews, v. 89, p. 143-170, https://doi.org/10.1016/j.oregeorev.2017.05.024.

Pitfield, P., Brown, T., Gunn, G., and Rayner, D., 2011, Tungsten - Mineral Profile: British Geological Survey, 34 p., http://www.bgs.ac.uk/mineralsUK/statistics/mineralProfiles.html

Polya, D., 1989, Chemistry of the main-stage ore-forming fluids of the Panasqueira W-Cu (Ag)-Sn deposit, Portugal; implications for models of ore genesis: Economic Geology, v. ${ }^{\circ} 84$, p. ${ }^{\circ} 1134-1152$, https://doi.org/10.2113/gsecongeo.84.5.1134.

Roedder, E., 1984, Fluid inclusions, Mineralogical Society of America, Reviews in Mineralogy Volume 12.

Romer, R.L., and Kroner, U., 2016, Phanerozoic tin and tungsten mineralization-Tectonic controls on the distribution of enriched protoliths and heat sources for crustal melting: Gondwana Research, v. 31, p. 60-95, https://doi.org/10.1016/j.gr.2015.11.002.

Schmidt, C., 2016, Tin Speciation in $\mathrm{H}_{2} \mathrm{O}+\mathrm{HCl}$ fluids to $600^{\circ} \mathrm{C}$ from Raman spectroscopy: 15th International Conference on Experimental Mineralogy, Petrology and Geochemistry, Zürich, Abstract Volume EMPG XV, p. 61.

Simonson, J., and Palmer, D.A., 1993, Liquid-vapor partitioning of $\mathrm{HCl}$ (aq) to 350 C: Geochimica et Cosmochimica Acta, v. 57, p. 1-7, https://doi.org/10.1016/0016-7037(93)90462-6.

Stemprok, M., 1967, Genetische Probleme der Zinn-Wolfram-Vererzung im Erzgebirge: Mineralium Deposita, v. 2, p. 102-118, https://doi.org/10.1007/BF00206583. 
-, 1987, Greienization (a review): Geologische Rundschau, v. 76, p. 169-175, https://doi.org/10.1007/BF01820580.

Stemprok, M., and Sulcek, Z., 1969, Geochemical profile through an orebearing Lithium Granite: Economic Geology and the Bulletin of the Society of Economic Geologists, v. 64, p. 392-404, https://doi.org/10.2113/gsecongeo.64.4.392.

Thomas, R., 1982, Ergebnisse der thermobarogeochemischen Untersuchungen an Flüssigkeitseinschlüssen in Mineralen der postmagmatischen Zinn-WolframMineralisation des Erzgebirges: Freiberger Forschungsheft, C 370, p. 1-85.

Tischendorf, G., Gottesmann, B., Foerster, H.-J., and Trumbull, R.B., 1997, On Libearing micas: Estimating Li from electron microprobe analyses and an improved diagram for graphical representation: Mineralogical Magazine, v. 61, p. 809-834, https://doi.org/10.1180/minmag.1997.061.409.05.

Vallance, J., Cathelineau, M., Marignac, C., Boiron, M.-C., Fourcade, S., Martineau, F., and Fabre, C., 2001, Microfracturing and fluid mixing in granites: W-(Sn) ore deposition at Vaulry (NW French Massif Central): Tectonophysics, v. 336, p. 43-61, https://doi.org/10.1016/S0040-1951(01)00093-2.

1GSA Data Repository item 2017xxx, Appendix DR1 (regional geology, methods, samples and further data) and Appendix DR2 (fluid inclu-sion data), is available online at http://www.geosociety.org/datarepository/2017/ or on request from editing@geosociety.org. 